\title{
TINJAUAN HUKUM ISLAM TERHADAP SISTEM JUAL BELI PULSA TOKEN LISTRIK (STUDI PADA PLN ULP POLEWALI)
}

\author{
suardi Kaco Sapri, \\ Prodi Hukum Ekonomi Syariah, Fakultas Agama Islam, Universitas Al Asyariah Mandar \\ saprivixion@gmail.com, kamarallingsuardi@yahoo.com
}

\begin{abstract}
Abstrak
Permasalahan dalam penelitian ini adalah konsumen akan mendapatkan kWh yang tidak sama dengan harga nominal uang yang dikeluarkan. Misalnya, konsumen membeli pulsa token listrik senilai Rp. $50.000,00$ maka kita hanya akan mendapatkan 33,70 kWh. Rumusan masalah dalam penelitian ini adalah bagaimana sistem jual beli pulsa token listrik di PLN ULP Polewali. Sedangkan tujuan dari penelitian ini adalah untuk mengetahui tinjauan hukum Islam terhadap sistem jual beli pulsa token listrik di PLN ULP Polewali. Penelitian ini merupakan penelitian lapangan (field research) dengan studi kasus yaitu suatu penelitian yang dilakukan di lapangan atau lokasi penelitian, suatu tempat yang terpilih sebagai lokasi untuk menyelidiki gejalah objektif yang terjadi di lokasi tersebut. Sumber data yang digunakan dalam penelitian ini adalah sumber data primer yaitu sumber data yang diperoleh langsung dari karyawan PLN ULP Polewali, pihak penjual serta pembeli dan sumber data sekunder yaitu sumber data yang diperoleh dari catatan dan buku-buku yang terkait dengan permasalahan yang penulis kaji. Pendekatan yang dilakukan adalah pendekatan deskriptif kualitatif. Metode pengumpulan data yang digunakan dalam penelitian ini adalah observasi, wawancara, dan dokumentasi. Hasil penelitian yang didapat dalam penelitian ini adalah praktik jual beli pulsa token listrik ini harga uang yang dikeluarkan tidak sama dengan $\mathrm{kWh}$ yang kita dapat. Praktik seperti ini tidak termasuk riba karena pulsa token listrik bukanlah mata uang rupiah, meskipun satuannya rupiah, sehingga tidak harus diperjual belikan secara tamatsul (dengan nilai yang sama). Hal ini dinyatakan sah dan diperbolehkan, karena terpenuhinya rukun dan syarat jual beli serta tidak bertentangan dengan hukum Islam.
\end{abstract}

Abstract

The problem in this study is that consumers will get $k W h$ which is not the same as the nominal price of the money spent. For example, consumers buy electricity token pulses worth Rp. 50.000,00 then we will only get $33.70 \mathrm{kWh}$. The formulation of the problem in this study is how to buy and sell electricity tokens at PLN ULP Polewali. While the purpose of this study is to find out the review of Islamic law on the electricity token sale and purchase system at PLN ULP Polewali. This research is a field research with a case study, namely a research conducted in the field or research location, a place chosen as a location to investigate objective phenomena that occur in that location. The data sources used in this study are primary data sources, namely data sources obtained directly from PLN ULP Polewali employees, sellers and buyers and secondary data sources, namely data sources obtained from records and books related to the problems that the authors examine. The approach taken is a qualitative descriptive approach. Data collection methods used in this study were observation, interviews, and documentation. The results obtained in this study are the practice of buying and selling pulses of electricity tokens, the price of money spent is not the same as the $k W h$ we get. This practice does not include usury because electricity token pulses are not rupiah currency, even though the unit is rupiah, so they do not have to be traded in tamatsul (with the same value). This is declared valid and permissible, because it fulfills the pillars and conditions of sale and purchase and does not conflict with Islamic law.

\section{PENDAHULUAN}

Listrik menjadi hal yang begitu penting untuk masyarakat saat ini, karena dengan menggunakan listrik menjadi kebutuhan dasar untuk berbagai fungsi. Listrik sebagai alat pendukung aktivitas manusia sehingga membuat masyarakat menjadi ketergantungan terhadap listrik. Oleh karena itu, PT. PLN (Persero) sebagai penyedia tenaga listrik yang memiliki peran mengatur dengan baik untuk kepentingan bersama.

PLN mengeluarkan kebijakan pada tahun 2010 tentang cara pembayaran listrik, yang dulunya masyarakat membayar tagihan listrik setiap bulannya dengan kata lain masyarakat menggunakan listrik terlebih dahulu kemudian membayarnya. Tetapi, sekarang ada kebijakan baru dari pihak PLN yaitu masyarakat mengeluarkan biaya terlebih dahulu kemudian 
menggunakan listrik atau disebut dengan Prabayar. Cara menggunakan listrik Prabayar yaitu, masyarakat membeli voucher di loket-loket penjualan kemudian masyarakat diberi nomor dua puluh digit yang nantinya dimasukkan ke dalam kilometernya, setelah angka dua puluh digit itu dimasukkan di kilometer maka otomatis kWh akan masuk di kilometer masyarakat sesuai dengan jumlah yang dibelinya.

Sampai saat ini masih banyak masyarakat yang belum mengetahui kenapa Kilo Watt Hour yang dia terima tidak sesuai dengan biaya yang dikeluarkan. Misalnya, masyarakat membeli pulsa token listrik senilai Rp. 50,000,00 maka dia hanya mendapatkan 33,70 Kilo Watt Hour. Atau saat kita membeli token PLN senilai Rp. 100.000,00 maka kita hanya mendapatkan 67 Kilo Watt Hour. Pihak PT. PLN menginformasikan kepada masyarakat kalau setiap voucher listrik yang di beli sudah termasuk:

a. Kwh (Kilo Watt Hour)

b. PPJ ( Pajak Penerangan Jalan), biayanya berbeda-beda setiap daerah.

c. Meterai. Meterai a d a dua, yaitu yang pertama, voucher token PLN senilai Rp. 250.000,00 Rp. 1.000.000,00 maka biaya meterai sebesar Rp. 3.000,00. yang kedua, pembelian token PLN senilai Rp. 1.000.000,00 ke atas maka biaya meterainya Rp. 6.000,00.

d. Biaya administrasi berbeda setiap bank atau gerai.

Dengan adanya biaya tambahan seperti biaya administrasi serta pajak penerangan jalan sebesar 10\% untuk daerah Polewali, serta harga per Kilo Watt Hour tergantung pada golongan tarif.।

Berdasarkan praktik jual beli pulsa token listrik, pembeli dan penjual dapat bertransaksi secara langsung (toko offline) maupun secara tidak langsung (online). Pembeli memberikan nomor ID pelanggan dan nomor meter listrik lalu kita menyebutkan nominal berapa yang kita isi selanjutnya kita akan diberikan 20 digit angka kode unik pada setruk, selanjutnya kita akan memasukkan 20 digit angka tersebut kedalam meteran untuk menambahkan pulsa yang telah di beli.

Diantara sekian banyak transaksi dalam aktivitas ekonomi manusia adalah praktik jualbeli. Jual beli merupakan satu perjanjian di antara dua pihak atau lebih, dimana masing- masing pihak mengikatkan diri untuk menyerahkan hak milik atas suatu barang sementara pihak yang lain membayar harga yang telah di janjikan.

Allah telah menetapkan aturan-aturan mengenai hukum yang berkaitan dengan jual beli seperti yang telah diungkapkan oleh ahli fikih, baik yang mengenai rukun, syarat, maupun bentuk jual beli yang di perbolehkan dan yang tidak di perbolehkan. Oleh karena itu, di dalam praktiknya harus di upayakan agar tidak keluar dari ketentuan-ketentuan yang sudah ada dalam hukum Islam, serta dapat memberikan manfaat bagi pihak- pihak yang bersangkutan. Akan tetapi adakalanya pula terjadi penyimpangan-penyimpangan dari aturan-aturan hukum yang telah ditetapkan, sehingga menyebabkan akad jual beli menjadi batal (tidak sah).

Berangkat dari latar belakang yang penulis tulis di atas perlu diadakan penelitian untuk mengetahui apakah praktik jual beli pulsa token listrik yang terapkan oleh PLN ULP Polewali sudah sesuai dengan hukum Islam atau malah bertentangan dengan hukum Islam yang ada. Kemudian, menuangkannya ke dalam sebuah karya ilmiah yang berjudul Tinjauan hukum Islam terhadap praktik jual beli pulsa token listrik di PLN ULP Rolewali. Diharapkan dari hasil kajian ini dapat dijadikan acuan dalam pelaksanaan transaksi jual beli pulsa token listrik. Maka peneliti menarik beberapa rumusan masalah yang nantinya akan menjadi fokus dalam penelitian ini antara lain sebagai berikut: Bagaimana sistem jual beli token listrik di PLN ULP Polewali? Bagaimana tinjauan hukum Islam tentang jual beli token listrik di PLN ULP Polewali? 


\section{TINJAUAN PUSTAKA}

\section{A. Pengertian Jual Beli}

Secara etimologis jual beli berarti menukar barang dengan harta. Adapun secara terminologis, maka ia berarti transaksi penukaran selain dengan fasilitas dan kenikmatan. Sengaja diberi pengecualian "fasilitas" dan "kenikmatan", agar tidak termasuk didalamnya penyewaan dan pernikahan. ${ }^{1}$

Didalam hukum Islam, jual beli termasuk ke dalam lapangan hukum perjanjian/perikatan atau 'aqd dalam bahasa Arab. Jual beli adalah proses pemindahan hak milik/barang atau harta kepada pihak lain dengan menggunakan uang sebagai alat tukarnya. Menurut etimologi, jual beli adalah alba'i, asy-syira', al-mubadah, dan at- tijarah. ${ }^{5}$ Secara terminologis, maka jual beli adalah transaksi penukaran selain dengan fasilitas dan kenikmatan. Pengecualian fasilitas dan kenikmatan, agar tidak termasuk didalamnya penyewaan dan pernikahan. ${ }^{2}$

Jual beli dalam istilah fiqh disebut dengan al-bai' yang berartti menjua, mengganti dan menukar sesuatu dengan sesuatu yang lain. Lafal al-ba' dalam bahasa arab terkadang digunakan untuk pengertian lawannya, yakni kata asy-syira' (beli). Dengan demikian, kata al-bai' berarti jual, tetapi sekaligus juga berarti beli. ${ }^{3}$

Secara bahasa, bai' adalah al-mubadalah (pertukaran), kata al-bai' mempunyai makna yang sama dengan kata al-syira'. Dua kata ini termasuk dalam kategori al-fadh al-musytarakah baina almutadladah. Sama seperti Muhammad Taufiq, Hasan Ayyub juga menyebutkan contoh yang sama, yaitu dengan menyebutkan surah Yunus ayat 20 dalam hal persamaan makna antara bai' dan syira'. Secara terminologi beliau berpendapat bahwa bai' berarti adanya pertukaran harta dengan harta dengan adanya keridhaan atau saling suka oleh kedua belah pihak yang melakukan transaksi. Disebutkan juga bahwa $b a ' i$ berarti jual beli atau pertukaran barang dengan harga, contohnya seperti baju dengan beberapa dinar. Sedangkan untuk transaksi barter atau pertukaran barang dengan barang biasa disebut ba'i muqayadlah. ${ }^{4}$

\section{B. Klasifikasi Jual Beli}

Jual beli diklasifikasikan dalam banyak pembagian dengan sudut pandang yang berbeda-beda. Kami akan menyebutkan bagian di antara pembagian tersebut: ${ }^{5}$

1. Klasifikasi jual beli dari sisi objek dagangan

Ditinjau dari sisi ini, jual beli di bagi menjadi tiga jenis. Yaitu:

a. Yang pertama jual beli umum, yaitu menukar uang dengan barang.

b. Yang kedua, jual beli ash-sharf atau money changer, yakni penukaran uang dengan uang.

c. Yang ketiga, jual beli muqayadha atau barter, yakni menukar barang dengan barang.

2. Klasifikasi Jual Beli Dari Sisi Standarisasi Harga.

a. Jual beli Bargaen (Tawar-menawar). yakni jual beli dimana penjual tidak memberitahukan modal barang yang dijualnya.

b. Jual beli amanah. Yakni jual beli di mana penjual memberitahukan harga modal jualnya. Dengan dasar jual beli ini, jenis jual beli tersebut terbagi menjadi dua jenis lain:

1) Jual beli murabahah, yakni jual beli dengan modal dan persentase keuntungan yang diketahui.

2) Jual beli wadhi'ah, yakni jual beli dengan harga di bawah modal dan jumlah kerugian yang diketahui.

\footnotetext{
${ }^{1}$ Shaleh ash-Shawi dan Abdullah al-Mushlih, fikih ekonomi islam, (cet. 5; Jakarta: Darul Haq, 2015), h. 87.

${ }^{2}$ Abdullah al-Mushlih dan Shalah ash-Shawi, Fikih Ekonomi Islam, (Cet. 1; Jakarta: Darul Haq,
} 2001), h. 87.

${ }^{3}$ Nasrun Haroen, fiqh muamalah, (cet 1; Jakarta: gaya media pratama, 2000), h. 111

${ }^{4}$ Hasan Ayyub, fiqh al-muamalat al-maliayah fi al-islam, (Kairo: Dar al-salam, 2006), h.7.

${ }^{5}$ Shaleh ash-Shawi dan Abdullah al-Mushlih, Fikih Ekonomi Islam, h. 88. 
c. Jual beli tauliyah, yakni jual beli dengan menjual barang dengan harga modal, tanpa keuntungan dan kerugian. Sebagian ahli fikih menambahkan lagi jenis jual beli yaitu jual beli isyrak dan mustarsil. Jual beli Isyrak adalah menjual sebagian barang dengan sebagian uang bayaran. Sedangkan jual beli mustarsal adalah jual beli dengan harga pasar. Jual beli muzayadah (lelang), yaitu jual beli yang dilakukan dengan cara barang ditawarkan kepada pembeli lalu pembeli menawar barang tersebut dengan harga yang lebih tinggi dari harga yang di ajukan dari pembeli pertama. Kebalikannya di sebut dengan jual beli munaqashah (obral). Yakni si pembeli menawarkan diri untuk membeli barang dengan kriteria tertentu, lalu para penjual berlomba menawarkan dagangannya, kemudian si pembeli akan membeli dengan harga termurah yang mereka tawarkan.

3. Pembagian jual beli dilihat dari cara pembayaran

Jual beli seperti ini terbagi menjadi beberapa bagian yaitu:

a. Jual beli dengan cara barang diserahkan secara langsung bersamaan dengan pembayarannya.

b. Jual beli dengan pembayaran tertunda.

c. Jual beli dengan penyerahan barang tertunda.

d. Jual beli dengan penyerahan barang dan pembayaran yang sama-sama tertunda.

\section{Bentuk-bentuk Jual Beli}

Jual beli dapat ditinjau dari beberapa segi. Ditinjau dari segi hukumnya, jual beli ada dua macam, yaitu jual beli yang sah menurut hukum dan batal menurut hukum. ${ }^{6}$

Ditinjau dari segi benda yang dijadikan objek jual beli dapat dikemukakan pendapat Imam Taqiyuddin (qifayat Al-Ahyar: 329) bahwa jual beli dibagi menjadi tiga bentuk, yaitu: ${ }^{7}$

1. Jual beli benda yang kelihatan

2. Jual beli yang disebutkan sifat-sifatnya dalamjanji.

3. Jual beli banda yang tidak ada.

Jual beli benda yang tidak ada serta tidak dapat di lihat dilarang oleh agama Islam karena barangnya tidak tentu atau masih gelap sehingga dikhawatirkan barang tersebut diperoleh dari curian atau barang titipan yang akibatnya dapat menimbulkan kerugian salah satu pihak. Syarbini Khatib menyebutkan bahwa penjualan bawang merah dan wortel serta yang lainnya yang berada dalam tanah adalah batal sebab hal tersebut adalah perbuatan gharar. $^{8}$

Akad jual beli yang dilakukan dengan lisan adalah akad yang dilakukan oleh banyak orang, sedangkan untuk orang bisu diganti dengan isyarat. Isyarat merupakan pembawaan alami dalam mengemukakan kehendak, yang dipandang dalam akad adalah maksud atau kehendak dan pengertian, bukan pembicaraan dan pernyataan. ${ }^{9}$

Penyampaian akad jual beli dapat dilakukan melalui utusan, perantara, tulisan atau suratmenyurat. Jual beli seperti ini sama dengan ijab qabul dengan ucapan, misalnya melalui kantor pos. Jual beli dilakukan antara penjual dan pembeli yang tidak berhadapan dalam satu majelis akad, tetapi melalui kantor pos, jual beli seperti ini dibolehkan menurut syara'. Dalam pemahaman sebagian ulama, bentuk ini hampir sama dengan jual beli salam. Pada jual beli salam, penjual dan pembeli saling berhadapan dalam satu majelis akad, adapun dalam jual beli melalui kantor pos, penjual dan pembeli tidak berada dalam satu majelis akad.

Jual beli yang dilarang dan batal hukumnya adalah sebagi berikut: ${ }^{10}$

a. Barang yang dihukumkan najis oleh agama, seperti babi, berhala, bangkai dan khamar. Rasulullah SAW. bersabda, "dari jabir r.a Rasulullah SAW. bersabda, sesungguhnya

${ }^{6}$ Siti Nur Fatoni, Pengantar Ilmu Ekonomi (Di Lengkapi Dasar-dasar Ekonomi Islam), (cet. 1; Bandung: Pustaka Setia, April 2014), h. 193.

${ }^{7}$ Siti Nur Fatoni, Pengantar Ilmu Ekonomi (Di Lengkapi Dasar-dasar Ekonomi Islam), h. 193.

${ }^{8}$ Siti Nur Fatoni, Pengantar Ilmu Ekonomi (Di Lengkapi Dasar-dasar Ekonomi Islam),h. 194.

${ }^{9}$ Siti Nur Fatoni, Pengantar Ilmu Ekonomi (Di Lengkapi Dasar-dasar Ekonomi Islam), h. 195

${ }^{10}$ Siti Nur Fatoni, Pengantar Ilmu Ekonomi (Di Lengkapi Dasar-dasar Ekonomi Islam), h. 196 
Allah dan rasul-Nya telah mengharamkan menjual arak, bangkai, babi dan berhala." (H.R. Bukhari dan Muslim)

b. Jual beli sperma hewan (apalagi sperma manusia), seperti mengawinkan seekor domba jantan dengan betina, agar memperoleh turunan. Jual beli ini haram hukumnya karena Rasulullah SAW. bersabda, "dari Ibnu Umar r.a. berkata, Rasulullah SAW. telah melarang menjual sperma binatang." (H.R. Bukhari dan Muslim)

c. Jual beli anak binatang yang masih berada dalam perut induknya. Jual beli seperti ini dilarang karena barangnya belum ada dan tidak tampak. Rasulullah SAW, bersabda, "dari ibnu Umar r.a. Rasulullah SAW. telah melarang penjualan sesuatu yang masih dalam kandungan induknya." (H.R. Bukhari dan Muslim)

d. Jual beli dengan muhaqallah. Haqalah mempunyai arti tanah, sawah dan kebun. Maksud muhaqallah di sini adalah menjual tanam-tanaman yang masih di ladang atau di sawah. Hal ini dilarang agama, sebab ada persangkaan riba di dalamnya.

e. Jual beli dengan mukhadharah. Yaitu menjual buah-buahan yang belum layak di panen, seperti menjual rambutan yang masih hijau, mangga yang masih kecil dan lainnya. Hal ini dilarang karena barang tersebut masih samar, dalam arti mungkin buah tersebut jatuh tertiup angin kencang atau lainnya sebelum diambil oleh pembelinya.

f. Jual beli dengan muammassa, yaitu jual beli secara sentuh menyentuh. Misalnya, seseorang menyentuh sehelai kain dengan tangannya pada malam atau siang hari, dan orang yang menyentuh berarti telah membeli kain tersebut. Hal ini dilarang karena mengandung tipuan dan kemungkinan akan menimbulkan kerugian bagi salah satu pihak.

g. Jual beli dengan munabadzah, jual beli secara lempar-melempar, seperti seseorang berkata, "lemparkanlah kepadaku apa yang ada padamu, nanti kulemparkan pula kepadamu apa yang ada padaku." Setelah terjadi lempar- melempar, terjadilah jual beli. Hal ini di larang karena mengandung tipuan dan tidak ada ijab dan qabul.

h. Jual beli dengan muzabanah, yaitu menjual buah yang basah dengan buah yang kering, seperti menjual padi kering dengan bayaran padi basah, sedangkan ukurannya dengan ditimbang, sehingga merugikan pemilik padi kering. Hal ini dilarang oleh Rasulullah SAW. dengan sabdanya, "dari Anas r.a., ia berkata, Rasulullah SAW. melarang jual beli: muhaqallah, mukhadharah, mulammassah, munabazah, dan muzabanah." (H.R. Bukhari)

i. Menentukan dua harga untuk satu barang yang diperjual belikan. Menurut Syafi'i, penjualan seperti ini mengandung dua arti. Pertama, seperti seseorang berkata, "saya jual biku ini seharga Rp. 5.000 dengan tunai atau Rp. 7.000 dengan cara utang." Arti kedua adalah seperti seseorang berkata, " saya jual bku ini padamu dengan syarat kamu harus menjual tasmu padaku." Rasulullah SAW. bersabda, "Dari Abi Hurairah, ia berkata, Rasulullah SAW. bersabda, barang siapa yang menjual dengan dua harga dalam satu penjualan barang, baginya ada kerugian atau riba'." (H.R. Abu Dawud).

j. Jual beli dengan syarat (iwadh mahjul). Jual beli seperti ini hampir sama dengan jual beli menentukan dua harga. Hanya, di sini dianggap sebagai syarat, misalnya seseorang berkata, "saya jual rumah jelek ini kepadamu dengan syarat kamu menjual mobilmu kepadaku)." Menurut Asy-Syafi' $i$, jual beli ini sama dengan jual beli dengan dua harga arti yang kedua.

k. Jual beli gharar, yaitu jual beli yang samar sehingga kemungkinan adanya penipuan, seperti penjualan ikan yang masih di kolam atau menjual kacang tanah yang atasnya tampak bagus, tetapi di bawahnya jelek. Penjualan seperti dilarang karena Rasulullah SAW. bersabda, "janganlah kamu membeli ikan di dalam air karena jual beli seperti termasuk gharar, atau menipu." (H.R. Ahmad).

1. Jual beli dengan mengecualikan sebagian dan benda yang dijual, seperti seseorang menjual sesuatu dari benda itu dengan mengecualikan salah satu bagiannya. Misalnya, A menjual seluruh pohon yang ada di kebunnya, kecuali pohon pisang maka jual beli ini sah sebab yang di kecualikannya jelas. Akan tetapi, apabila yang dikecualikannya tidak jelas (majhul), jual beli tersebut batal. Rasulullah SAW. bersabda, "Rasulullah melarang jual beli dengan muhaqallah, mudzabanah, dan yang dikecualikan, kecuali bila ditentukan." (H.R. An-Nasa'i). 
m. Larangan menjual makanan sehingga dua kali ditakar. Hal ini menunjukkan adanya ketidakpercayaan antara penjual dan pembeli. Jumhur ulama berpendapat bahwa seseorang yang membeli sesuatu dengan takaran dan telah diterimanya, sehingga ia harus menakarnya untuk pembeli yang kedua itu. "Rasulullah SAW. melarang jual beli makanan yang dua kali ditakar, dengan takaran penjual dengan takaran pembeli.” (H.R. Ibnu Majah dan Daruquthni).

\section{Rukun dan Syarat Jual Beli}

Agar jual beli dapat dilaksanakan secara sah dan memberi pengaruh yang tepat, harus direalisasikan beberapa syaratnya terlebih dahulu. Ada yang berkaitan dengan pihak penjual dan pembeli, dan ada kaitan dengan objek yang diperjualbelikan. ${ }^{11}$

Jual beli mempunyai rukun dan syarat yang harus dipenuhi, sehingga jual beli itu dapat dikatakan sah oleh syara'. ${ }^{12}$ Dalam menentukan rukun jual beli, terdapat perbedaan pendapat ulama Hanafiyah dengan jumhur ulama. Rukun jual beli menurut ulama Hanafiyah hanya satu, yaitu ijab (ungkapan membeli dari pembeli) dan qabul (ungkapan menjual dari penjual). Menurut mereka yang menjadi rukun dalam jual beli itu hanyalah kerelaan (ridahara' dhu) kedua belah pihak untuk melakukan transaksi jual beli. Akan tetapi, karena unsur kerelaan itu merupakan unsur hati yang sulit untuk diindera sehingga tidak kelihatan, maka diperlukan indikasi yang menunjukkan kerelaan itu dari kedua belah pihak. Indikasi yang menunjukkan kerelaan kedua belah pihak yang melakukan transaksi jual, menurut mereka, boleh tergambar dalam ijab dan qabul, atau melalu cara saling memberikan barang dan harga barang (ta'a'thi).

1. Rukun jual beli ada lima, yaitu: ${ }^{13}$

a. Penjual, penjual harus orang yang memiliki barang dijual atau ia diberi izin untuk menjualkannya dan haruslah orang yang pintar, bukan orang yang idiot.

b. Pembeli, pembeli harus orang yang diperbolehkan melakukan transaksi, yaitu bukan orang yang idiot atau anak kecil yang belum diizinkan untuk melakukan transaksi.

c. Barang yang dijual, barang yang dijual harus barang yang suci, dapat diserah terimakan, diketahui oleh pembeli meskipun dengan sifat- sifatnya.

d. Lafal akad (transaksi), yaitu ijab dan qabul, baik dengan ucapan, misalnya "juallah kepadaku sekian," lalu si penjual berkata, "ini saya jual kepadamu." Atau dengan perbuatan, misalnya pembeli berkata, "juallah pakaian itu kepadaku." Lalu si penjual menyerahkan barang tersebut kepadanya.

e. Saling rela, maka tidak sah jual beli tanpa disertai kerelaan dari kedua belah pihak. Akan tetapi, jumhur ulama menyatakan bahwa rukun jual beli itu ada empat yaitu:

a. Ada orang yang berakad atau al-muta'aqidain ( penjual dan pembeli)

b. Ada shighat ( lafa; ijab dan qabul).

c. Ada barang yang di beli.

d. Ada nilai tukar pengganti barang.

Menurut ulama Hanafiyah, orang yang berakad, barang yang dibeli dan nilai tukar barang termasuk ke dalam syarat-syarat jual beli, bukan rukun jual beli.

2. Syarat orang yang berakad

Para ulama fiqh sepakat menyatakan bahwa orang melakukan akad jual beli itu harus memenuhi syarat:

a. Berakal. Oleh sebab itu, jual beli yang dilakukan anak kecil yang belum berakal dan orang gila, hukumnya tidak sah. Adapun anak kecil yang sudah mumayyiz, menurut ulama Hanafiyah, apabila akad yang dilakukannya membawa keuntungan bagi dirinya, seperti menerima hibah, wasiat, dan sedekah, maka akadnya sah. Sebaliknya apabila akad itu membawa kerugian bagi dirinya, seperti meminjamkan hartanya kepada orang lain,

${ }^{11}$ Shaleh ash-Shawi dan Abdullah al-Mushlih, Fikih Ekonomi Islam, h. 89.

${ }_{13}^{12}$ Nasrun Haroen, fiqh muamalah, h. 114

${ }^{13}$ Abu Bakar Jabir al-Jazairi, Minhajul Muslim: pedoman hidup seorang muslim; alih bahasa ihwanuddin Abdullah dan Taufik Auliah Rahman, ( cet. 1; Jakarta: Ummul Qura), h. 688. 
mewakafkan, atau menghibahkannya, maka tindakan hukumnya ini tidak boleh dilaksanakan. Apabila transaksi yang dilakukan anak ligus, seperti jual beli, sewa menyewa, dan perserikatan dagang, maka transaksi ini hukumnya sah, jika walinya mengizinkan. Dalam kaitan ini, wali anak kecil yang telah mumayyiz itu benar-benar mempertimbangkan kemaslahatan anak kecil itu. Jumhur ulama berpendirian bahwa orang yang melakukan akad jual beli itu harus telah baliqh dan berakal. Apabila orang yang berakad itu masih mumayyiz, maka jual belinya tidak sah, sekalipun mendapat izin dari walinya.

b. Yang melakukan akad itu adalah orang berbeda. Artinya, seseorang tidak dapat bertindak dalam waktu yang bersamaan sebagai penjual, sekaligus pembeli.

\section{E. Dasar Hukum Jual Beli}

Jual beli sebagai bagian dari muamalah mempunyai dasar hukum yang jelas, baik dari AlQur'an, Al-Sunnah dan telah menjadi ijma Ulama dan kaum muslimin. Bahkan jual beli bukan hanya sekedar muamalah, akan tetapi menjadi salah satu media untuk melakukan kegiatan untuk saling tolong menolong sesamamanusia.

Landasan atau dasar hukum mengenai jual beli disyariatkan berdasarkan Al- Qur'an, Hadist Nabi, dan Ijma yakni:

1. Al-Qur'an. Firman Allah Swt. dalam QS.Al-Baqarah/ $2: 275^{14}$

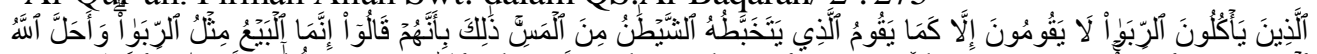

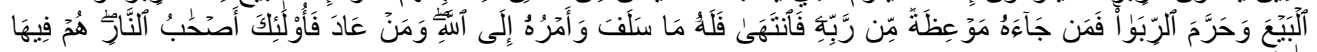

Terjemahannya:

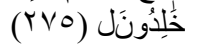

Orang-orang yang makan (mengambil) riba tidak dapat berdiri melainkan seperti berdirinya orang yang kerasukan syaitan lantaran (tekanan) penyakit gila. Keadaan mereka yang demikian itu adalah disebabkan mereka berkata (berpendapat), padahal Allah telah menghalalkan jual beli dan mengharamkan riba. Orang-orang yang telah sampai kepadanya larangan dari Tuhannya, lalu terus berhenti (dari mengambil riba), maka baginya apa yang telah diambilnya dahulu (sebelum datang larangan); dan urusannya (terserah) pada Allah. Orang yang mengulang (mengambil riba), maka orang itu adalah penghuni- penghuni neraka; mereka kekal di dalamnya.

Ayat di atas secara umum tapi tegas memberikan gambaran tentang hukum kehalalan jual beli dan keharaman riba. Allah SWT tegas menghalalkan jual beli dan mengharamkan riba. Meskipun keduanya (jual beli maupun riba) sama-sama mencari keuntungan, namun terdapat perbedaan yang mendasar dan signifikan terutama dari sudut pandang cara memperoleh keuntungan disamping tanggung jawab risiko kerugian yang kemungkinan timbul dari usaha ekonomi itu sendiri.

2. Surah Al-Baqarah/2 : 198

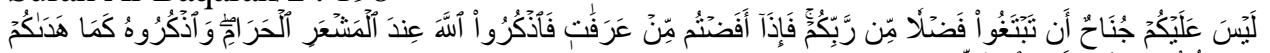

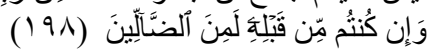

Terjemahannya:

“Tidak ada dosa bagimu untuk mencari karunia (rezki hasil perniagaan) dari Tuhanmu. Maka apabila kamu telah bertolak dari Arafah, berzikirlah kepada Allah di Masya'aril Haram. Dan berzikirlah (dengan menyebut) Allah sebagaimana yang ditunjukkan-Nya kepadamu; dan sesungguhnya kamu sebelum itu benar-benar termasuk orang-orang yang sesat."

\section{F. Batal dan Berakhirnya Jual Beli}

Batal (bathil) yang berarti sia-sia atau tidak benar. Dikatakan batal yaitu akad yang menurut dasar dan sifatnya tidak diperbolehkan seperti akad yang menurut dasar dan sifatnya tidak diperbolehkan seperti yang tidak memenuhi salah satu rukun dan syarat, dapat diringkas sebagai berikut: ${ }^{15}$

1. Bahwa akad tersebut tidak ada wujudnya secara syar'i (secara syar'i tidak pernah dianggap

\footnotetext{
${ }^{14}$ Departemen agama, Al-Qur'an dan terjemahan, h. 37.

${ }^{15}$ Syamsul Anwar, Hukum Perjanjian Syariah, (Jakarta: Raja Grafindo Persada, 2007), h. 245.
} 
ada), dan oleh karena tidak melahirkan akibat hukum apapun.

2. Bahwa apabila telah dilaksanakan oleh para pihak akad bathil itu wajib dikembalikan kepada keadaan semula pada waktu sebelum dilaksanakannya akad bathil tersebut.

3. Akad bathil tidak berlaku pembenaran dengan cara memberi izin misalnya, karena transaksi tersebut didasarkan kepada akad yang sebenarnya tidak ada secara syar'i dan juga karena pembenaran hanya berlaku terhadap akaq mauquf.

4. Akad bathil tidak perlu di-fasath (dilakukan pembatalan) karena akad ini sejaka semula adalah batal dan tidak pernah ada.

5. Ketentuan lewat waktu (at-taqadum) tidak berlaku terhadap kebatalan.

\section{G. Pulsa Token}

Pulsa adalah media penghubung untuk komunikasi, baik komunikasi jarak dekat maupun jarak jauh. Definisi pulsa juga dapat diartikan sebagai alat perhitungan atau sistem perhitungan dalam menentukan tarif pelanggan. Fungsi pulsa adalah sebagai satuan biaya untuk melakukan komunikasi/telepon, mengirim pesan short messenger service (SMS), chating, messenger (WA, BBM, FB, dll) dan bahkan untuk bermain game online (dengan pembelian paket data tentunya).

Pulsa adalah alat satuan perhitungan biaya telepon, sebelum masuknya kita ke era telepon genggam, istila ini memang tidak terlalu populer diantara kita karena memang PSTN atau fixek line lebih ke arah perhitungan tagihan (pascabayar) jadi pakai dulu baru bayar walhasil tidak ada istilahnya habis. ${ }^{16}$

Token listrik atau listrik pintar merupakan layanan listrik prabayar yang memungkinkan pelanggan untuk mengendalikan sendiri penggunaan listriknya sesuai kebutuhan dan kemampuannya. Seperti halnya pulsa isi ulang pada telepon seluler, pada sistem listrik pintar, pelanggan terlebih dahulu membeli pulsa (voucher/token) listrik isi ulang melalui gerai ATM sejumlah bank atau melalui loketloket pembayaran tagihan listrik online. ${ }^{17}$

\section{III.METODE PENELITIAN}

\section{A. Jenis dan Lokasi Penelitian}

Penelitian ini menggunakan jenis metode penelitian kualitatif lapangan, yaitu jenis penelitian yang menggambarkan secara kualitatif mengenai objek yang di bicarakan sesuai kenyataan yang terdapat dalam masyarakat. ${ }^{41}$ Lokasi penelitian penulis di PLN ULP Polewali.

Dalam penelitian ini, penulis menggunakan pendekatan kualitatif deskriptif, Sumber data yang diperoleh dari penelitian ini adalah: Data Primer, dan Data Sekunder. Teknik pengumpulan data dengan Observasi, Wawancara dan Dokumentasi

\section{B. Instrumen Penelitian}

Instrumen penelitian yang di maksud peneliti adalah, agar dapat membantu dalam pelaksanaan penelitian seperti:
1. Lis Pertanyaan
2. Kamera
3. Handpone yang berfungsi sebagai alat perekam.

\section{Teknik Pengolahan dan Analisis Data}

Dalam rangka menjawab rumusan masalah, analisis data yang mengacu pada penelitian ini dan beberapa tahapan yang di jelaskan dari Miles dan Huberman yang meliputi:

1. Pengumpulan data

\footnotetext{
16 admin@pojokpulsa.co.id, http://pojokpulsa.co.id/pulsal, (2018)

${ }^{17}$ PT PLN (Persero), https:/www.pln.co.id/pelanggan/listrik-pintar, (2020)
} 
2. Reduksi data

3. Sajian data

4. Penarikan,

\section{Pengujian Keabsahan Data}

Pengujian keabsahan data ini menggunakan teknis trianulasi dan lebih mengutamakan efektivitas proses dan hasil yang diinginkan. Trianulasi dilakukan dengan menguji apakah proses dan hasil metode yang diinginkan sudah berjalan dengan baik seperti:

1. Pastikan apakah setiap hari telah terhimpun catatan wawancara dengan informan serta catatan harian observasi.

2. Dilakukan uji silang terhadap materi catatan-catatan harian itu untuk memastikan apakah tidak ada informasi yang bertentangan antara wawancara dan catatan observasi.

3. Hasil konfirmasi itu perlu diuji lagi dengan informasi-informasi sebelumnya.

\section{IV.HASIL PENELITIAN}

\section{A. Sistem Jual Beli Pulsa Token Listrik di PLN ULP Polewali}

Dalam kehidupan kita terdapat macam-macam jual beli, salah satunya bentuk jual beli pulsa token listrik. PT. PLN sebagai penyedia pulsa token listrik namun tidak menjual pulsa token listrik di unit-unit area kantor PT. PLN akan tetapi PLN bekerja sama dengan pihak BANK, PT. POS Indonesia dan Payment Point lainnya. Dalam teknis pembelian pulsa listrik melalui Automatic Money Changer (ATM) diatur ketentuannya oleh masing-masing payment Point. Dalam penjualan pulsa token listrik ini pembeli dapat memilih berapa tarif pulsa yang diinginkan, PLN menyediakan pulsa dimulai Rp. 20,000,00 - Rp. 1,000,000,00 namun jumlah kWh yang didapati tidak akan sama dengan jumlah uang yang kita keluarkan karena adanya tarif tenaga listrik dan biaya-biaya lain, seperti pajak penerangan jalan yang ditentukan oleh pemerintah, biaya administrasi dan materai jika pembelian pulsa di atas Rp. 250,000,00.

Hasil wawancara terhadap pihak-pihak yang berkaitan dengan penelitian penulis. Yaitu:

1. Bapak Latif

"ini sekarang banyak sekalimi kubayar listrik satu bulan, nasampai Rp. 200.000.00,-. Padahal waktu pakaika kilometer Pasca Bayar cuman sekitar Rp. 100.000.00,- ji kubayar satu bulan"18

Bapak Latif adalah seorang petani yang menggunakan listrik Pra Bayar. Dia mengatakan kepada penulis bahwa dia harus mengeluarkan biaya Rp. 200.000.00,- dalam sebulan untuk listrik dan itu lebih mahal dibandingkan dengan saat dia menggunakan kilometer Pasca bayar yang hanya mengeluarkan biaya sekitar Rp. 100.000.00,- dalam sebulan.

2. Ibu Lia

"kayak lebih banyak kurasa masuk voucherku kalau belika di bapak Randi pulsa daripada di Mukani"19

Ibu Lia adalah seorang ibu rumah tangga, dia mengatakan bahwa pada saat dia membeli voucer listrik yang Rp, 50.000.00,- di loket penjualan itu berbeda saat dia membeli voucer listrik yang harga Rp. 50.000.00,- di loket penjualan bapak Randi

3. Ibu Nurlaela

"kalau ada yang mau beli pulsa sama saya na', saya minta dulu nomor kilometernya baru saya kirimkammi. Kalau adami masuk laporannya, saya tuliskammi nomornya yang mau nakasi masuk di kilometernya." 20

Ibu Nurlaela adalah seorang ibu rumah tangga yang menjual pulsa elektrik dan token listrik. Ia berjualan di rumah saja dengan menggunakan satu handphone. Beliau menjual pulsa sudah hampir satu tahun dan mendeposit pulsa dari agen pulsa topindo. Sistem penjualan pulsa ini

${ }^{18}$ Bapak Latif, Petani/Konsumen, Kec.Matakali Kab.Polewali Mandar, Sulbar, Wawancara Oleh Penulis Di Desa Indo Makkombong 11 Februari 2020

${ }^{19}$ Ibu Lia, Ibu Rumah Tangga/Konsumen, Kec.Matakali Kab.Polewali Mandar, Sulbar, Wawancara Oleh Penulis Di Desa Indo Makkombong 11 Februari 2020

${ }^{20}$ Nurlela, Ibu Rumah Tangga/Konsumen, Kec.Matakali Kab.Polewali Mandar, Sulbar, Wawancara Oleh Penulis Di Desa Nene Bece, 12 Februari 2020. 
yaitu Beliau mendapatkan kode angka untuk bertransaksi. Contoh: misalnya Hasnawati mendeposit seharga Rp. 500.000,00 lalu agen pulsa topindo memberikan sebuah kode untuk bertransaksi. Jika ada seseorang yang membeli pulsa sebesar Rp. 50.000,00 deposit tersebut akan berkurang sebesar Rp. 50.600,00 lalu Beliau akan mendapatkan sms yaitu laporan dari pengirimannya tadi yang di dalamnya terdapat kode angka token yang berjumlah 20 digit yang akan diberikan kepada pembeli. Lalu Beliau akan menjualnya dengan harga Rp. 53.000,00 kepada pembeli. Jadi, Beliau akan mendapatkan keuntungan sebesar Rp. 2.400,00.

4. Bapak I Gusti Bagus Wedyayawa Adi Prabawa

“begini de', pulsa lampu dengan pulsa hp itu tidak sama. Kalau pulsa hp, beliki pulsa Rp. 50.000,00, Rp. 50.000,00 juga masuk. Tidak sama kalau pulsa lampu, beliki pulsa Rp. $50.000,00$ yang masuk tidak cukup Rp. 50.000,00. Cuma 33kWh." 21

Bapak I Gusti Bagus Wedyayawa Adi Prabawa adalah karyawan dari kantor PLN ULP Polewali. Beliau menjelaskan bahwa perlu diketahui juga kalau pulsa token listrik itu berbeda dengan pulsa handphone. Kalau misalkan kita mau membeli pulsa handphone Rp. 50.000,00, yang masuk ke handphone kita juga Rp. 50.000,00. Sedangkan pulsa token listrik, yang masuk bukan Rupiah tapi energi listrik kWh. Misalkan kita beli Rp. 50.000,00 yang masuk di kilometer itu 33 $\mathrm{kWh}$, bukan Rp. 33.000,00. kWh itu adalah satuan energi listrik. Cara perhitungan kalau kita membeli pulsa listrik, misalkan kita membeli Rp.50.000,00 itu pasti dipotong pajak penerangan jalan (PPJ), setiap daerah PPJ nya itu berbeda-beda. Kalau di Polewali 10\%, jadi Rp. 50.000,00 dikurangi $10 \%$ itu Rp. 45.000,00, dikurangi lagi biaya admin Rp. 2.500,00 jadi sisa Rp. 42.500,00. Kemudian, biaya Rupiah per kWh itu beda-beda tiap tarifnya. Jadi, kalau misalkan ibu rumah tangga, Rupiah per kWhnya itu Rp. 1.467,00. Misalkan kita beli pulsa token listrik Rp. 50.000,00, rumusnya itu: (pulsa - PPJ : Rupiah per kWh). Contoh: Rp. $50.000-10 \%$ :Rp. $1.467=30,674 \mathrm{kWh}$. Hasilnya ini, yang akan masuk di kilometer kita.

Sistem jual beli pulsa token listrik di PLN Rayon polewali adalah kerja sama antara pihak PLN dengan payment point. Pihak PLN hanya sebagai penyedia pulsa token listrik saja sedangkan untuk penjual token listrik membeli melalui Bank. Penulis telah mewawancarai dua penjual token listrik, Bapak Randi (agen BRILink) dan Ibu Nurlela (penjual pulsa token listrik di rumah). Kedua sistem ini sebenarnya sama saja yang membedakan jika kita membeli pulsa token listrik di agen BRILing kita mengetahui berapa besar $\mathrm{kWh}$ yang di dapat serta rincian biaya PPJ dan biaya admin karena tertera di struk transaksi yang kita dapat sedangkan jika kita membeli pulsa token listrik di rumah Ibu Nurlela bahwa rincian $\mathrm{kWh}$ yang didapat serta biaya PPJ tidak kita ketahui karena tidak adanya struk.

Dalam pembelian pulsa token listrik ini kita dapat melakukan transaksi offline dan online. Pembelian melalui offline terdapat tempat yang dapat kedua belah pihak bertemu secara langsung untuk melakukan akad, seperti konter pulsa dan Minimarket. Sedangkan jika menggunakan transaksi online kedua belah pihak tidak dapat bertemu secara langsung. Pembelian dengan menggunakan sistem online masyarakat dapat menggunakan aplikasi seperti payfazz atau topindo. Tujuh dari sepuluh orang pembeli pulsa token listrik di BRILink atau konter pulsa sedangkan untuk pembelian melalui online hanya ada tiga konsumen saja. Biaya admin yang dikenakan Rp. 2,500,00.

Pembelian pulsa token listrik yang kita beli jumlah $\mathrm{kWh}$ yang kita dapati tidak akan sama dengan uang yang kita keluarkan karna adanya tarif daya listrik serta biaya-biaya lainnya.

Praktik jual beli pulsa token listrik di PLN ULP Polewali:

a. Subjek atau Pelaku

1) Subjek atau pelaku yang melakukan perjanjian jual beli pulsa token listrik, yaitu pihak penjual dan pembeli

2) Dalam pelaksanaan jual beli pulsa token listrik pada umumnya pembeli sudah

21 I Gusti Bagus Wedyayawa Adi Prabawa, Pegawai PLN ULP Polewali, Kec.Polewali Kab. Polewali Mandar, Sulbar Wawancara Oleh Penulis Di Kantor PLN ULP Polewali, 11 Februari 2020 
dewasa dan cakap dalam melakukan hukum. Karena pembeli sudah mampu membedakan yang baik dan yang buruk bagi dirinya dan dalam keadaan sehat jasmani maupun rohani dalam melaksanakan jual beli pulsa token listrik.

Berdasarkan hal ini, dilihat dari subjek atau pelakunya dalam melaksanakan perjanjian jual beli pulsa token listrik secara hukum sudah benar atau sah.

b. Objek

Syarat-syarat objek dalam perjanjian jual beli

1) Dalam pelaksanaan jual beli pulsa token listriknya yaitu berupa objek pulsa token listrik dalam hal ini objeknya suci dan bersih karena bukan arak, bangkai, babi, anjing, atau berhala yang dihukumi najis oleh al- Qur'an.

2) Objeknya diperkenankan oleh hukum

Pulsa token listrik bukan merupakan barang yang tidak diperkenankan oleh hukum, baik secara hukum positif maupun hukum Islam, pulsa token listrik termasuk barang yang bisa di manfaatkan karena merupakan kebutuhan manusia untuk dapat menggunakan listrik.

3) Dimungkinkan untuk dilaksanakan

Objek dalam perjanjian ini dapat diserahkan secara langsung oleh pihak penjual kepada pembeli dan dapat melakukan perjanjian secara langsung antara penjual dan pembali.

c. Adanya unsur paksaan atau tidak diantara penjual dan pembeli

Dalam praktik yang terjadi pulsa token listrik merupakan produk PLN ULP Polewali yang bekerja sama dengan paymen point untuk menjual pulsa token listrik kepada masyarakat. Dalam hal ini pihak-pihak sama-sama rela dalam melaksanakan perjanjian jual beli.

\section{B. Tinjauan Hukum Islam Tentang Sistem Jual Beli Pulsa Token Listrik di PLN ULP Polewali}

Dalam urusan muamalah, memperhatikan kebaikan-kebaikan manusia adalah hal mendasar dalam syariat Islam dan meminimalisir kemafsadatan bagi umat manusia. Oleh karena itu Islam memberikan batasan-batasan terhadap pola perilaku manusia agar dalam setiap tindakannya tidak menimbulkan kemadharatan baik bagi dirinya sendiri maupun bagi pihak lain. Dengan demikian di harapkan setiap manusia dapat mengambil manfaat antara satu dan yang lain dengan jalan yang sesuai dengan norma-norma agama tanpa kecurangan dan kebatilan.

Sebagaimana firman Allah dalam Q.S An-Nisa'/4: 29.

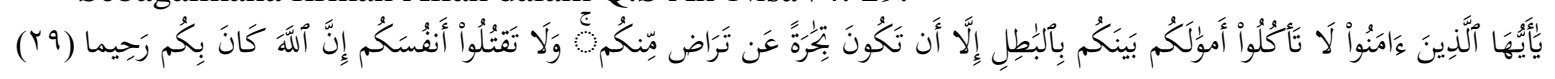

Terjemahannya: Wahai orang-orang yang beriman! Janganlah kamu saling memakan harta sesamamu dengan jalan yang batil (tidak benar), kecuali dalam perdagangan yang berlaku atas dasar suka sama suka di antara kamu. Dan janganlah kamu membunuh dirimu. Sungguh, Allah Maha Penyayang kepadamu.

Jual beli merupakan bagian dari saling tolong menolong (ta'awun). Bagi pembeli menolong yang membutuhkan uang (keuangan), sedangkan menurut penjual juga berarti menolong pembeli yang sedang membutuhkan barang. Karenanya, jual beli itu adalah perbuatan yang mulia dan pelakunya mendapatkan keridhaan Allah SWT. bahkan Rasulullah SAW menegaskan bahwa penjual yang jujur dan benar kelak di akhirat akan di tempatkan bersama para Nabi, Suhada, dan orang-orang saleh. Hal ini sesuai dengan hadits yang di riwayatkan At-Tirmizi menunjukkan tingginya derajat penjual yang jujur dan benar.

Jika dianalisa dalam tinjauan Islam, maka praktik jual beli pulsa token di PLN ULP Polewali tidak bertentangan dengan hukum Islam karena pulsa token listrik memiliki nilai dan merupakan komoditi yang umum di perdagangkan di zaman modern ini. Pulsa juga tidak termasuk barang yang diharamkan untuk diperjualbelikan karena tidak ada dalil yang mengharamkannya Pembelian pulsa token listrik ini harga uang yang kita keluarkan tidak sama dengan $\mathrm{kWh}$ yang kita dapat. Karena 
dengan adanya biaya pajak penerangan jalan, biaya admin, dan biaya materai ini tidak termasuk riba, karena pulsa token listrik bukanlah mata uang rupiah, meskipun satuannya rupiah, sehingga tidak harus dijual belikan tamatsul (dengan nilai yang sama).

\section{PENUTUP}

Berdasarkan hasil analisis data yang berhasil dihimpun oleh penulis dalam judul skripsi “Tinjauan Hukum Islam Terhadap Sistem Jual Beli Pulsa Token Listrik Di PLN ULP Polewali", maka penulis mengambil beberapa kesimpulan sebagai berikut:

1. Praktik jual beli pulsa token listrik yang di lakukan oleh PT.PLN sebagai penyedia pulsa token listrik yang melakukan kerja sama dengan payment point untuk melakukan penjualan. Harga yang ditetapkan untuk jual beli pulsa token listrik merupakan kebijakan dari PLN dengan adanya daya tarif listrik, biaya pajak penerangan jalan (pajak daerah), namun biaya admin ditentukan oleh masing-masing paymen point.

2. Pandangan hukum Islam tentang jual beli pulsa token listrik dinyatakan sah dan diperbolehkan, karena terpenuhinya rukun dan syarat jual beli serta tidak bertentangan dengan hukum Islam.

\section{DAFTAR PUSTAKA}

Departemen agama, Al-Qur'an dan terjemahan.

Ayyub, Hasan. fiqh al-muamalat al-maliayah fi al-islam. (Kairo: Dar al-salam, 2006).

Esterbg. Metodologi Penelitian Kualitatif Dan Kuantitatif. (Yokyakarta: Bumi Aksara, 2002).

Fatoni, Siti Nur. Pengantar Ilmu Ekonomi (Di Lengkapi Dasar-dasar Ekonomi Islam), (cet. 1; Bandung: Pustaka Setia, April 2014).

Haroen, Nasrun . fiqh muamalah, (cet 1; Jakarta: gaya media pratama, 2000)

Hendi Suhendi, Fiqh Muamalah. (Jakarta: PT Raja Grafindo Persada, 2010).

al-Jazairi Abu Bakar Jabir. Minhajul Muslim: pedoman hidup seorang muslim; alih bahasa ihwanuddin Abdullah dan Taufik Auliah Rahman. ( cet. 1; Jakarta: Ummul Qura).

al-Khalafi Abdul Azhim bin Badawi, al-Wajiz fi Fiqh al-Sunnah wa al-Kitab al-Azis, terj. Ma'ruf Abdul Jalil. (Cet. III; Jakarta: Pustaka As-Sunnah, 2007).

Moleong, Lexi J. Metode Penelitian Kualitatif. Remaja Rosdaakarya, Bandung: 2007.

Muslich, Ahmad Wardi fiqh muamalat. (cet.1; Jakarata: Amzah. 2010).

al-Mushlih Abdullah dan Shalah ash-Shawi, Fikih Ekonomi Islam, (Cet. 1;Jakarta: Darul

Mochtar Naim, kompendium Himpunan Ayat-ayat Al-Qur'an yang berkaitan dengan Hukum, (Jakarta: Hasanah, 2001).

Nazir, Moh. Metode Penelitian. Ghalia Indonesia, 2005.

Pln123@pln.co.id,https://www.pln.co.id/tentang-kami/profil-perusahaan, (Jakarta: Webmail, diakses Tanggal 08 Maret 2020).

PT PLN (Persero), https:/www.pln.co.id/pelanggan/listrik-pintar, (2020)

ash-Shawi Shaleh dan Abdullah al-Mushlih, fikih ekonomi islam, (cet. 5; Jakarta: Darul Haq, 2015).

Sohari Sahrani dan Ru'fah Abdullah, fikih muamalah, (Bogor: Ghaliah Indonesia, 2011).

Soekanto, Soejono. Metode Penelitian Hukum, (Jakarta: UII Pres, 198 